International Journal of Social Science (IJSS)

Vol.1 No.2 August 2021, pp: 55-68

ISSN: 2798-3463 (Printed) | 2798-4079 (Online)

DOI: https://doi.org/10.53625/ijss.v1i2.137

\title{
THE INFLUENCE OF GUARANTEE VALUE, BUSINESS TURNOVER, BUSINESS AGE AND PROVISION OF ACCOUNTING INFORMATION ON FORMAL CREDIT ACCESS TO SMES IN BANYUMAS DISTRICT
}

\author{
By \\ Alfiandita Rizka Meivita ${ }^{1}$, Yusriyati Nur Farida ${ }^{2}$ \\ ${ }^{1,2}$ Department of Accounting, Faculty of Economics and Business University Jenderal Soedirman, Indonesia \\ Email: yusriyati_nur_farida@yahoo.com
}

\begin{tabular}{l}
\hline \hline Article Info \\
\hline Article history: \\
Received May 19, 2021 \\
Revised June 26, 2021 \\
Accepted July 21, 2021 \\
\\
\hline Keywords: \\
Collateral Value \\
Business Turnover \\
Business Age Accounting \\
Provision Of Anformation \\
Access To Formal Credit
\end{tabular}

\begin{abstract}
One of the main problems faced by Small and Medium Enterprises (SMEs) is capital. The limited capital owned by SMEs encouraged them to obtain loans by accessing credit from financial institutions. However, not all SMEs can access credit from financial institutions because before giving credit the creditor needs to gain confidence that the prospective debtor isable to repay his credit based on 5C credit principles (character, capacity, capital, condition of economy, collateral). This study aims to determine the effect of collateral value, business turnover, business age and provision of accounting information on accessibility of formal credit. The type of research used is survey research. The population in this study are all SMEs engaged in the trade sector in Banyumas Regency. The sampling technique used is proportionate stratified sampling with a sample of 100 respondents. Data collection techniques in this study used survey techniques by distributing questionnaires to respondents. The data analysis technique in this study used multiple regression analysis assisted by SPSS software. The results of this study indicate that: (1) collateral value has a significant positive effect on access to formal credit, (2) business turnover has a significant positive effect on access to formal credit, (3) business age has no significant influence on access to formal credit, (4) information provision accounting has a significant positive effect on access to formal credit. Adjusted $R$ Square testing results show that the effect of collateral value, business turnover, business age, and provision of accounting information on access to formal credit is $54.7 \%$ while $45.3 \%$ can be explained by other variables not examined. The implication of this research is to be able to increase access to formal credit, SMEs need to (1) own assets that can be used as collateral where the value must be greater than the amount of credit proposed, (2) improve their ability to manage businesses to obtain optimal business turnover, (3) strive to improve the provision of accounting information appropriately so that it can facilitate financial institutions to assess actual business conditions
\end{abstract}

This is an open access article under the CC BY-SA license.

Corresponding Author:

Alfiandita Rizka Meivita

University Jenderal Soedirman

Email: yusriyati_nur_farida@yahoo.com

Journal homepage: https://bajangjournal.com/index.php/IJSS 


\section{INTRODUCTION}

In Indonesia, Micro, Small and Medium Enterprises (MSMEs) are the business groups that have the largest number and are proven to be resilient in facing various economic crises. The number of MSMEs in Indonesia is always growing every year, as many as 59,262,772 units in 2015 and growing to 62,922,617 units in 2017 (Ministry of Cooperatives and SMEs, 2017). The development of MSMEs plays an important role in encouraging Indonesia's economic growth. The contribution of MSMEs can be seen from the high absorption of labor, the increase in Gross Domestic Product (GDP), as well as the increase in the country's foreign exchange.

Table 1. MSMEs Data Development for 2015-2017

\begin{tabular}{|c|c|c|c|c|c|c|c|}
\hline \multirow[t]{2}{*}{ Indicator } & \multirow[t]{2}{*}{ unit } & \multicolumn{2}{|c|}{2015} & \multicolumn{2}{|c|}{2016} & \multicolumn{2}{|l|}{2017} \\
\hline & & amount & $\begin{array}{c}\text { Share } \\
\%\end{array}$ & amount & $\begin{array}{c}\text { share } \\
\%\end{array}$ & amount & Share $\%$ \\
\hline $\begin{array}{l}\text { BusinessU } \\
\text { nit }\end{array}$ & Unit & 59.262 .772 & 99,9 & 61.651 .177 & 99,9 & 62.922 .617 & 99,9 \\
\hline labor & Person & 123.229 .386 & 96,7 & 112.828 .610 & 97,1 & 116.673 .416 & 97,1 \\
\hline $\begin{array}{l}\text { GDP on } \\
\text { basis of } \\
\text { constant } \\
\text { price }\end{array}$ & $\begin{array}{l}\text { Rp (in } \\
\text { billion) }\end{array}$ & 1.655 .430 & 57,7 & $5.171 .063,6$ & 57,2 & $5.425 .414,7$ & 57,1 \\
\hline
\end{tabular}

\begin{tabular}{llllllll}
$\begin{array}{l}\text { Total } \\
\text { Non oil exports }\end{array}$ & $\begin{array}{l}\text { Rp } \\
\text { (in } \\
\text { billion) }\end{array}$ & $185.975,0$ & 15,7 & $255.126,1$ & 14,4 & $298.208,7$ & 14,2 \\
\hline
\end{tabular}

Source: Ministry of Cooperatives and SMEs, 2017

In Table 1 above, it can be seen that the number of MSMEs in Indonesia reaches $99.9 \%$ and employment reaches $97.1 \%$, this means that the increasing number of MSMEs will increasingly provide job opportunities for the Indonesian people so as to reduce the unemployment rate. In addition, the contribution of MSMEs to GDP is bigger than that of large businesses, reaching 57.1\%. Many MSMEs have also developed their market share not only on a national scale but also internationally. It can be seen from table 1, that the number of MSMEs exports increases every year so that it affects the increase in the country's foreign exchange earnings.

However, even though MSMEs have an important role and make a considerable contribution to the country's economy, this business sector still faces various problems, one of which is capital problems (Octavianti, 2017). Based on the theory of capital structure, there are two sources of capital that can be used to fund a business, namely loan capital and own capital (Riyanto, 2011:296). The limited capital owned by MSMEs encourages them to obtain loans by accessing credit from financial institutions. This is in accordance with the pecking order theory proposed by Myers (1984) which states that external debt financing (credit) is based on an internal funding deficit (Sugiarto, 2009:50).

However, not all MSMEs can access credit from financial institutions (Etnerprise and Ayalew, 2015). Based on the presentation of the Yogyakarta National Coordination Meeting (2018), only 30.4\% of MSMEs in Central Java have accessed credit from banks. Meanwhile, in Banyumas Regency only 8.3\% of MSMEs have access to banks (Adawiyah, 2013). To overcome the problem of low MSME lending, Indonesia Bank (BI) issued a regulation requiring banks to provide a 15\% portion of credit to MSMEs in 2017. However, in reality it is still difficult to implement because banks in distributing credit prioritize the precautionary principle (nasional.sindonews.com/). This is regulated in Law Number 10 of 1998 concerning Banking which stipulates that in providing credit, creditors must have confidence that the debtor is able to pay off his debts in accordance with the agreement.

Based on the information found when the researchers conducted a pre-research survey on September 28, 2018 to BRI, BPD Central Java and Bukopin Bank Purwokerto branch, there are several things that creditors (Banks) to pay attention before approving credit applications made by MSMEs. The Bank's analysis of credit approvals begins with looking at the track records of prospective borrowers through the Debtor Information System (SID), while for new debtors, credit analysts will conduct in-depth interviews. If the track record or interview results of the prospective borrower are declared good, then the Bank will then conduct a survey to the business location. The purpose of the survey is to ensure that the object to be financed actually exists. In the survey, the Bank will also assess whether the 
International Journal of Social Science (IJSS)

Vol.1 No.2 August 2021, pp: 55-68

ISSN: 2798-3463 (Printed) | 2798-4079 (Online)

DOI: https://doi.org/10.53625/ijss.v1i2.137

value of the collateral provided is in accordance with the value of the proposed credit. Then, to gain confidence that the prospective borrower can pay the installments, the Bank needs to know the level of turnover obtained by looking at the accounting records. In addition, only whose business has been running for at least six months can apply for credit to the bank, especially the People's Business Credit.

From the findings in the pre-research survey, it can be seen that there are factors that can affect the success or failure of MSMEs in accessing credit, namely the value of collateral, business turnover, business age and provision of accounting information. In accordance with the principle of collateral credit, the guarantee provided by the prospective borrower must have a value greater than the value of the proposed credit (Kasmir, 2012:89). According to Adawiyah's research (2013), the low access to credit for MSMEs in Banyumas Regency is caused by the absence of collateral or the mismatch between the value of the guarantee provided and the amount of credit applied for. This statement is in accordance with research conducted by Kurniawan (2014) which states that there is a positive effect of guarantees on access to finance for MSME loans. However, this is different from the research conducted by Adinekso (2010) which states that the guarantee factor does not affect the accessibility of MSMEs to banking.

Another factor that affects MSMEs access to formal credit is the limited ability to pay installments (Adawiyah, 2013). In the principle of granting capacity credit, the debtor's ability to repay credit can be assessed from the financial aspect (the ability to generate profits) (Suhardjono, 2003:199). Based on the financial aspect, the ability of MSMEs to repay loans can be seen from the total turnover obtained. Research conducted by Hardinata (2014) states that business turnover has a positive effect on lending decisions to SMEs. This is because business turnover is a form of business performance measurement that is used as an indicator to assess the ability of prospective debtors to repay their loans. Meanwhile, the research conducted by Adirinekso (2010) showed different results that the MSMEs capacity factor in paying installments had no effect on MSMEs access to banking.

In the principle of providing capacity credit, the ability of MSMEs to repay loans can also be assessed from the aspect of management or the ability to manage a business (Suhardjono, 2003:199). The ability of the owner to manage the business can be seen from the age of the business. The longer the business has been running, the more it affects the owner's ability to maintain the continuity of his business (Thanh et al, 2011). This is in accordance with Mersha and Ayenew's research (2017) which states that business age has a positive effect on access to bank credit for Micro and Small Enterprises. The study explains that older companies have stronger relationships with financial institutions or banks so that they have better access to credit than younger companies. On the other hand, research conducted by Sujarwo (2016) states that there is no significant positive relationship between length of business and access to credit for MSMEs.

In addition, accounting information is also a guideline for creditors to assess whether or not the company is eligible for distribution of funds, as well as material for consideration of how much loan will be given (Sholikha, 2015). However, there are still many MSMEs that do not make accounting records, making formal credit service providers need to be careful in providing credit because they cannot know the actual condition of MSMEs (Maisyaroh and Paramita, 2018). In fact, providing accounting information can help SMEs in accessing credit from formal financial institutions (Maghfiroh et al., 2018). This is in accordance with research conducted by Marsha and Ayenew (2017) which states that accounting information has a positive effect on access to credit in Micro and Small Enterprises. However, this is not in accordance with the research of Kurniawan (2014) which states that financial information has a negative effect on access to finance for MSME loans.

This study only focuses on Small and Medium Enterprises (SMEs) because according to Kuncoro (2015) explains that micro business actors prefer to get additional capital from family, relatives and informal institutions compared to accessing credit at the bank. Based on the background of the problem, the researchers are interested in conducting research with the title "The Influence of Collateral Value, Business Turnover, Business Age and Provision of Accounting Information on Access to Formal Credit for SMEs in Banyumas district".

\section{LITERATURE REVIEW AND HYPOTHESES FORMULATION} Capital Structure Theory

Capital structure is a comparison between loan capital and own capital. Capital sourced from loans is obtained from bonds, investments and debt. While the own capital is obtained from share capital, retained earnings and reserve funds. Capital structure is an important issue for every company, because good or bad of the capital structure will have a direct impact on the company's financial position (Riyanto, 2011:296).

The capital structure of each company is determined by taking into account various aspects on the basis of the possibility of access to funds, the company's courage to take risks, the owner's strategic plan, as well as an analysis of the costs and benefits obtained from each source of funds. In each source of funds that can be used by the company, there are advantages and disadvantages related to the status of the company. Companies with closed status, and not yet 
limited liability companies generally rely on their own capital for funding and debting to third parties (creditors) (Sugiarto, 2009: 2).

Likewise with SMEs, they tend to use their own capital to finance their business as much as possible and will access credit when they need additional funding. According to Michaelas, et al. (1998), small business owners follow the pecking order theory to fulfill their business funding needs. In the pecking order theory proposed by Myers (1984), it is stated that external debt financing (credit) is based on an internal funding deficit (Sugiarto, 2009:50).

Credit Principles (5C)

According to article 8 paragraph 1 of Law no. 10 of 1998 concerning Banking stipulates in providing credit, creditors are required to have confidence based on depth analysis of the intentions and abilities and ability of the debtor to pay off his debts in accordance with the agreement. This confidence can be obtained from the results of a credit assessment carried out based on credit principles with 5C analysis (Kasmir, 2012:101):

a) Character

Character is the nature or personality of a person. Character analysis is carried out with the aim of providing confidence to the creditor that the nature or personality of the people to be given credit can be trusted. This confidence can be obtained by looking at the background of the borrower (debtor), both work and personal backgrounds such as lifestyle, and family circumstances.

b) Capacity

Capacity analysis is carried out to measure the level of debtor's ability to repay loans from the business to be financed, which includes management aspects (ability to manage the company), production aspects (ability to market products), personnel aspects (the ability of workers to support company activities), and aspects financial (ability to generate profit) (Suhardjono, 2003:199).

c) Capital

Capital analysis aims to measure the ability of debtors to provide their own capital to support business financing. The greater ability of the debtor to provide their own capital, the smaller portion of financing made by the creditor. In conducting a capital analysis, it also includes the size and composition of capital, the development of operating profit, the ratio of debt to equity ratio and the development of ups and downs in stock prices (for companies that go public) (Suhardjono, 2003:211).

d) Condition of Economy

Condition of economy is defined as a situation in which political, social, economic and cultural conditions affect the state of the economy which may affect the smooth running of businesses that obtain credit (Muljono, 2001:17). In assessing credit, current and future economic conditions should also be assessed according to each sector. e) Collateral

Collateral is handed over by the debtor to the creditor as security tools if the debtor is unable to pay off his credit (Muljono, 2001:16). Collateral should exceed the amount of credit granted. The function of the guarantee is to protect the creditor from the risk of loss.

\section{The Effect of Collateral Value on Access to Formal Credit in SMEs}

One of the main problems faced by SMEs is capital. In the theory of capital structure, it is explained that there are two sources of capital, loan capital and own capital (Riyanto, 2011:296). The limited capital owned by SMEs, encourages them to access credit from formal financial institutions. This is in accordance with the pecking order theory which states that external funding (credit) is based on an internal funding deficit (Sugiarto, 2009:50). However, not all SMEs can access credit from financial institutions, because based on Law Number 10 of 1998 article 8 (1) concerning Banking, the creditor before granting credit, needs to gain confidence that the debtor has the ability to repay his credit. This confidence can be obtained from the results of a credit assessment carried out based on credit principles by analyzing $5 \mathrm{C}$, one of which is collateral (Kasmir, 2012:101). The collateral value variable is used in this study to present the principle of collateral credit

Kurniawan (2014) conducted a study to identify the factors that influence finance access for MSME loans in Brebes Regency. From this research, it can be identified that collateral has a positive effect on access to finance for MSME loans. Ownership of assets as credit guarantees has an impact on the probability of access to loan finance for MSMEs. This means, the greater guarantee in submitting a credit plan, the higher probability of access to financial guarantees will be. The results of this study are in accordance with Mersha and Ayenew's research (2017) which states that guarantees have a positive and significant effect on access to bank credit for micro and small businesses.

Oktavianti et al. (2017) and Maisyaroh and Paramita (2018) also conducted research on access to formal credit for MSMEs. The independent variable in this study is credit terms with the collateral value as a measurement dimension to measure the credit terms variable. The results of both studies state that credit requirements in the form of collateral 
International Journal of Social Science (IJSS)

Vol.1 No.2 August 2021, pp: 55-68

ISSN: 2798-3463 (Printed) | 2798-4079 (Online)

DOI: https://doi.org/10.53625/ijss.v1i2.137

value have a positive effect on access to formal credit for MSMEs. The research of Nkundabannyanga (2014) also found similar results to the research of Oktavianti et al. (2017) and Maisyaroh and Paramita (2018) which state that credit requirements in the form of collateral value have a positive effect on access to formal credit for SMEs in Uganda. Another study about the effect of collateral value on access to formal credit was conducted by Adawiyah (2013). The results of the study indicate that the weak access of MSMEs to capital is due to unavailability of collateral or incompatibility of collateral value provided the credit value proposed. Financial institutions do not provide loans to MSMEs because they do not have confidence in MSMEs to repay loans on time. So to minimize this risk, many financial institutions ask collateral as a condition for applying credit. Based on this information, the following hypotheses can be formulated:

H1: Guarantee value has a positive effect on access to formal credit for SMEs.

Effect of Business Turnover on Access to Formal Credit for SMEs

In the principle of providing credit, namely capacity, before deciding to provide credit to prospective debtors, financial institutions will assess the ability of prospective debtors to pay installments and pay off their loans on time. The limited ability of debtors to pay installments at the bank is one of the factors that causes the weak access of MSMEs to capital (Adawiyah, 2013). Sholikha's research (2015) also states that the capacity variable has a significant positive effect on lending decisions by banks. Better capacity of the debtor, the higher the level of trust of the creditor to decide in providing credit. The ability of a debtor to pay credit installments can be determined by the amount of business turnover obtained each month.

Research conducted by Hardinata (2014) states that business turnover is the highest priority after collateral value, which affects the considerations of financial institutions in providing credit to SMEs. This is based on the analysis that business turnover is a form of measuring business performance as an indicator that leads directly to the ability of prospective customers to repay loans. Another study conducted by Kusumaningtyas (2016) states that the greater the turnover of the debtor's business, the net income he will get will be even greater so that his ability to pay credit installment obligations is getting better. In addition, business turnover is also a material consideration in determining a number of credit ceiling values that will be provided by the bank. Based on this information, it can be concluded that the greater the business turnover obtained by an SME, it will increase the confidence of financial institutions in providing credit to increase access to SME credit. Then the hypothesis can be formulated as follows:

H2: Business turnover has a positive effect on access to formal credit for SMEs.

\section{Effect of Business Age on Access to Formal Credit in SMEs}

The principle of granting capacity credit can also be assessed from the aspect of management or the ability to manage a business (Suhardjono, 2003:199). The ability to manage a business can be shown from the variable age of the business. The longer the company is established, the longer it shows its ability to face risks in managing its business so that creditors will be more confident in providing credit (Sholikha, 2015). Mersha and Ayenew (2017) conducted a study on access to formal financial sources for Micro and Small enterprises (MSEs) in Ethiopia. The results of this study indicate that the age of business has a positive effect on access to bank credit at MSEs. Company age is one of the factors that affect the company's access to bank loans, where older companies have stronger relationships with financial institutions or banks so that access to credit is better than younger companies.

The results of Martha and Satria's research (2015) reveal that the largest MSME group experiencing rejection is under 1 year of age, and the lowest experiencing rejection for the proposed loan is the MSME group that has been in business for more than 10 years. This study supports the research results of Thanh et al. (2011) which states that the obstacle for SMEs in accessing finance is the young age of the business. In addition, research by Rudiantoro and Veronica (2012) also states that business age has a positive effect on the amount of credit received by MSMEs. Banks will be more willing to provide larger loans to companies that have been around for a long time, because the business risk is smaller than companies that have just been established. The longer the business has been running, it is considered that the business owner is more experienced in managing his business and can maintain the continuity of his business. Based on this information, the following hypotheses can be formulated:

H3 : Age of business has a positive effect on access to formal credit in SMEs.

\section{Effect of Provision of Accounting Information on Access to Formal Credit in SMEs}

In the principle of credit capital, credit analysts will measure the ability of prospective debtors to provide their own capital to support business financing. The size of the capital owned can be assessed from the company's financial statements, so that the creditor can determine whether or not the prospective debtor is eligible to obtain credit (Muljono, 2001:15). However, there are still many SMEs that do not keep accounting records, making it difficult for SMEs to access credit from financial institutions. This is because formal credit service providers need to be careful in providing credit because they cannot know the actual condition of SMEs (Maisyaroh and Paramita, 2018). 
Research conducted by Juita (2016) regarding the use of accounting information systems in MSMEs in the trade service sector states that MSMEs have difficulty growing because they have major obstacles in accessing and obtaining funding. This is because there is asymmetry of information related to MSMEs so that it can create high business risks, especially financial risks. The bank is not able to accurately assess the credit worthiness of MSMEs due to the lack of information and the incompleteness of required documents that MSMEs are able to provide, especially those relating to the MSME's financial performance history.

Mersha and Ayenew's research (2017) on the determinants of formal credit access in MSEs states that accounting information has a positive effect on access to credit in micro finance institutions. The results of the study found that banks find it difficult to evaluate their business because MSEs do not have proper accounting procedures and records, they easily mix business proceeds with their personal money. This is in accordance with research conducted by Sholikha (2015) which states that accounting information has a significant positive effect on credit decisions. From the results of this study, it can be seen that when prospective debtors apply for credit, as a requirement, the creditor will ask for accounting information as a form of creditor assessment to see the company's financial performance. Based on this information, the following hypothesis can be formulated:

H4: The provision of accounting information has a positive effect on access to formal credit for SMEs.

\section{RESEARCH METHODS}

\section{Population and Sampling Techniques}

This type of research is quantitative research. Population in this study is Small and Medium Enterprises (SMEs) which are engaged in the trade sector in Banyumas, with SME owners as respondents who have accessed formal credit at least once. The sample of this study was determined using the proportionate stratified sampling technique. The data were collected in a survey method, namely distributing a list of questions in a questionnaire that was filled out or answered by the respondents.

\section{Data analysis technique}

Pilot Test

The pilot test was conducted to test the respondents' understanding of the words used in the questionnaire and aimed at a small number of respondents (Cooper and Schindler, 2014:85).

\section{Validity test}

Validity test is used to measure the validity of a questionnaire. A questionnaire is valid if the questions on the questionnaire are able to reveal something that will be measured by the questionnaire (Ghozali, 2009:49).

\section{Reliability Test}

Reliability test is a measuring tool to measure a questionnaire which is an indicator of a variable or construct. A questionnaire is reliable if a person's answer statement is consistent from time to time (Ghozali, 2009:45).

Descriptive statistics

Provide a description of a data seen from the average value, standard deviation, maximum value, and minimum value (Ghozali, 2009:19).

\section{Classic assumption test}

Normality test is used to test whether the residual value in the regression model is normally distributed or not (Suliyanto, 2011:69). Normality test in this study was carried out using Kolmogorov Smirnov. In the Kolmogorov Smirnov test, the data is said to be normally distributed if the significance value is $>0.05(\alpha=5 \%)$.

Multicollinearity test aims to test whether in the regression model there is a correlation between the independent variables or not (Suliyanto, 2011:81). The nature of multicollinearity in research variables can be seen from the value of Variance Inflation Factor (VIF). If the value of VIF < 10 then the model is declared not to contain multicollinearity. Heteroscedasticity test aims to test whether there is an inequality of variance from the residual of one observation to another observation in the regression model. To detect in a regression model by doing the Glejser Test. If the probability value is $>(0.05)$ or tcount ttable at a value of $=0.05$, there is no heteroscedasticity (Suliyanto, 2011:95). Multiple Regression Analysis

This method is a regression technique used to measure the effect of the independent variable on the dependent variable. In multiple regression, the independent variable is more than one. The equation model is as follows:

$$
Y=a+\beta 1 X 1+\beta 2 X_{2}+\beta 3 X_{3}+\beta 4 X 4+\mathrm{e}
$$

Explanation :

\begin{tabular}{|c|c|}
\hline $\mathrm{Y}$ & $=$ access to formal credit \\
\hline$a$ & $=$ constant \\
\hline$B_{1}$ & $=$ guarantee value of regression coefficient \\
\hline$\beta_{2}$ & $=$ business turnover of regression coefficient \\
\hline
\end{tabular}


International Journal of Social Science (IJSS)

Vol.1 No.2 August 2021, pp: 55-68

ISSN: 2798-3463 (Printed) | 2798-4079 (Online)

DOI: https://doi.org/10.53625/ijss.v1i2.137

\begin{tabular}{|c|c|}
\hline$\beta 3$ & $=$ business age of regression coefficient \\
\hline$\beta 4$ & $=$ regression coefficient for providing accounting information \\
\hline$X_{1}$ & $=$ guarantee value \\
\hline$X_{2}$ & $=$ business turnover \\
\hline$X_{3}$ & $=$ business age \\
\hline$X 4$ & $=$ provision of accounting information \\
\hline e & $=$ residual value \\
\hline
\end{tabular}

\section{Coefficient of Determination}

The coefficient of determination is the magnitude of the contribution of the independent variable to the dependent variable. If the value of the coefficient of determination is close to one, the higher ability of the independent variable in explaining the variation of changes to the dependent variable (Suliyanto, 2011:55).

\section{Partial test (t test)}

The value of $t_{\text {count }}$ is used to test the partial effect (per variable) on the dependent variable. The value of $t_{\text {count }}$ must be greater than the value of $t_{\text {table }}$ with df (degree of freedom): , (n-k) at a certain level of significance. With a significant level $(\alpha)$ of 0.05 , the criteria for testing Hypotheses 1,2,3 and 4 are as follows (Suliyanto, 2011:56):

1. $\mathrm{H}_{0}$ is accepted if: $\mathrm{t}_{\text {count }} \leq \mathrm{t}_{\text {table }}$ or $>0.05$

2. $H_{a}$ is accepted if: $t_{\text {count }}>t_{t a b l e}$ or $\leq 0.05$ and the direction of the coefficient is positive.

\section{RESULTS AND DISCUSSION}

\section{Pilot Test}

The results of the pilot test showed that the respondents considered the statements in the questionnaire to be understandable and the language understood so it could be used for research.

\section{Validity test}

Each statement item for the variable providing accounting information has an $r_{\text {count }}$ that is greater than $r_{\text {table }}$ with a significance level of $=0.05$ so it can be concluded that all statement items for the variable providing accounting information $\left(\mathrm{X}_{4}\right)$ are declared valid.

\section{Reliability Test}

Cronbach's Alpha value for the variable providing accounting information (X4) has a value greater than 0.60 so it can be concluded that all statements on the variable are declared reliable.

\section{Descriptive statistics}

Respondents' answers to questions about collateral value, business turnover, business age, provision of accounting information and access to formal credit can be described using a descriptive statistical table which can show the average value, standard deviation, minimum value and maximum value as following :

Table 2. Results of Descriptive Statistical Analysis

\begin{tabular}{lccccc}
\hline \multicolumn{1}{c}{ Variable } & N & $\begin{array}{c}\text { Minimum } \\
\text { value }\end{array}$ & $\begin{array}{c}\text { Maximum } \\
\text { value }\end{array}$ & Mean value & $\begin{array}{c}\text { Standard } \\
\text { Deviasiation }\end{array}$ \\
\hline Guarentee vallue (Ln_X1) & 100 & 17,25 & 21,64 & 19,2916 & 0,89801 \\
Business turnover (Ln_X2) & 100 & 17,07 & 19,52 & 17,6396 & 0,71171 \\
Business age (X3) & 100 & 7,00 & 540,00 & 102,8500 & 90,28847 \\
$\begin{array}{l}\text { Provision of accounting } \\
\text { information (X4) }\end{array}$ & 100 & 2,14 & 5,00 & 4,0486 & 0,77008 \\
Access to formal credit (Y) & 100 & 40,00 & 100,00 & 80,4073 & 22,03446 \\
\hline
\end{tabular}

Source: Processed Primary Data, 2019

Based on table 2, it can be seen that each variable has an average value that is greater than standard deviation value, it can be concluded that the average value can represent the overall data well.

The guarantee value variable has a minimum value of 17.25 or $\quad$ Rp. 31,000,000. Meanwhile, the maximum value for the guarantee value variable is 21.64 or Rp. 2,500,000,000. Thus, the average value of the guarantee value variable is 19.2916 or Rp. 353.430 .000

The business turnover variable has the lowest value of 17.07 or Rp. $26,000,000$ and the highest value of 19.52 or Rp. 300,000,000. Then obtained an average value of 17.6396 or Rp. 63.41 million. 
The business age variable has a minimum value of 7 months. Meanwhile, the maximum value for the variable age of business is 540 months. So the average value for the variable age of business is 102.85 or rounded up to 103 months.

The variable for providing accounting information has a minimum value of 2.14 and a maximum value of 5.00. Thus, the average value for the variable of providing accounting information is 4.0486 , which means that the provision of accounting information carried out by SMEs is classified as good.

The formal credit access variable has the lowest value of $40 \%$ and the highest value of $100 \%$. Thus, the average value is 80.4073 or rounded to $80.41 \%$.

\section{Classic assumption test}

\section{a) Normality Test}

Table 3 is the result of the Kolmogorov-Smirnov One-Sample statistical test which is used to test the normality of the data. Table 8 shows that the Asymp value. Sig. (2-tailed) is 0.113 greater than the value of (0.05) so it can be concluded that the data in this study are normally distributed.

Table 3. Normality Test Results

\begin{tabular}{ccccc}
\hline Variable & $\begin{array}{c}\text { Asymp. } \\
\text { Sig. }\end{array}$ & A & Explanation \\
\hline Standardized Residual & 0,113 & $>$ & 0,05 & Normal Distribusion \\
\hline
\end{tabular}

5. Source: Processed Primary Data, 2019

b) Multicollinearity Test

Multicollinearity test is done by looking at the value of VIF (Variance Inflation Factor). Based on table 4, it is known that the VIF value of the guarantee value variable, business turnover, business age and provision of accounting information is less than 10 , it can be stated that the regression model formed does not occur multicollinearity.

\begin{tabular}{lccc}
\hline \multicolumn{1}{c}{ Variable } & Tolerance & VIF & explanation \\
\hline Guarantee value (X1) & 0,585 & 1,709 & There is no multicollinearity \\
Business turnover (X2) & 0,669 & 1,495 & There is no multicollinearity \\
Business age (X3) & 0,902 & 1,109 & There is no multicollinearity \\
Provision of accounting & 0,915 & 1,093 & There is no multicollinearity \\
information (X4) & & & \\
\hline
\end{tabular}

Source: Processed Primary Data, 2019

c) Heteroscedasticity Test

The heteroscedasticity test was carried out using the Glejser test with the criteria if the probability value was > 0.05, then the regression model did not contain elements of heteroscedasticity. Based on table 5, the results of the heteroscedasticity test obtained a significance value greater than 0.05 , so it can be stated that the model does not contain elements of heteroscedasticity for all variables in the study.

Table 5. Heteroscedasticity Test Results

\begin{tabular}{|c|c|c|c|c|}
\hline Variable & Sig. & & A & explanation \\
\hline Guarantee value (X1) & 0,064 & $>$ & 0,05 & There is no heteroscedasticity \\
\hline $\begin{array}{l}\text { Business turn over } \\
\left(\mathrm{X}_{2}\right)\end{array}$ & 0,416 & $>$ & 0,05 & There is no heteroscedasticity \\
\hline Business age (X3) & 0,178 & $>$ & 0,05 & There is no heteroscedasticity \\
\hline $\begin{array}{l}\text { Provision of accounting } \\
\text { information (X4) }\end{array}$ & 0,854 & $>$ & 0,05 & There is no heteroscedasticity \\
\hline
\end{tabular}

Source: Processed Primary Data, 2019

Multiple Regression Analysis

Multiple regression analysis can be performed if the research regression equation is normally distributed, there is no multicollinearity, and there is no heteroscedasticity. Multiple regression analysis was tested using IBM SPSS Statistics 24 software for windows.

Table 6. Results of Multiple Regression Analysis

\begin{tabular}{|c|c|c|c|c|c|c|c|}
\hline Variable & $\begin{array}{l}\text { Regresi } \\
\text { coefisien }\end{array}$ & tcount & & ttable & Sig. & & $\alpha$ \\
\hline Guarantee value (X1) & 0,453 & 5,123 & $>$ & 1,661 & 0,000 & $<$ & 0,05 \\
\hline Business turnover (X2) & 0,237 & 2,866 & $>$ & 1,661 & 0,005 & $<$ & 0,05 \\
\hline
\end{tabular}


International Journal of Social Science (IJSS)

Vol.1 No.2 August 2021, pp: 55-68

ISSN: 2798-3463 (Printed) | 2798-4079 (Online)

DOI: https://doi.org/10.53625/ijss.v1i2.137

\begin{tabular}{|c|c|c|c|c|c|c|c|}
\hline Business age (X3) & 0,052 & 0,734 & $<$ & 1,661 & 0,465 & $>$ & 0,05 \\
\hline $\begin{array}{l}\text { provision of accounting } \\
\text { information }(\mathrm{X} 4)\end{array}$ & 0,307 & 4,337 & $>$ & 1,661 & 0,000 & $<$ & 0,05 \\
\hline constant & $=-300,36$ & & & & & & \\
\hline
\end{tabular}

Source: Processed Primary Data, 2019

Based on the results of Table 6 , the following regression equation is obtained:

$\mathrm{Y}=-\mathbf{3 0 0}, 365+0,453 \mathrm{X} 1+0,237 \mathrm{X} 2+0,052 \mathrm{X} 3+0,307 \mathrm{X} 4+e$

Keterangan:

\begin{tabular}{|c|c|}
\hline Y & $=$ Access to formal credit \\
\hline $\mathrm{X} 1$ & $=$ Business turn over \\
\hline $\mathrm{X} 2$ & $=$ Business turnover \\
\hline $\mathrm{X} 3$ & $=$ Business age \\
\hline $\mathrm{X} 4$ & $\begin{array}{l}=\text { Provision of accounting information } \\
=\text { error }\end{array}$ \\
\hline
\end{tabular}

The multiple regression equation explains several things as follows:

a) A constant of -300.365 means that if the guarantee value variable (X1), business turnover (X2), business age (X3) and the provision of accounting information (X4) is zero, it is likely that the loan application will not be approved by the formal credit provider institution. A negative value on this constant can be interpreted that there is no credit that can be accessed by the respondent.

b) The coefficient of the guarantee value variable (X1) which is 0.453 has a positive regression coefficient sign. This means that an increase in the value of collateral can be followed by an increase in access to formal credit.

c) The coefficient of business turnover variable (X2), which is 0.237 , has a positive regression coefficient sign. This means that an increase in business turnover can be followed by an increase in access to formal credit.

d) The variable coefficient of business age (X3), which is 0.052 , has a positive regression coefficient sign. This means that the increase in business age can be followed by an increase in access to formal credit.

e) The variable coefficient of accounting information provision (X4), which is 0.307 , has a positive regression coefficient sign. This means that the more accounting information provided, the more formal credit access can be.

\section{Goodness of Fit Test}

Table 7 shows that the Fcount value is $30.876>$ Ftable is 2.4674 with a significance value $(0.000)<(0.05)$. Based on the results of the $\mathrm{F}$ test in Table 7, the regression model is feasible to use to explain the effect of the independent variable on the dependent variable. A significant $\mathrm{F}$ test result means that the regression equation model used into the fit criteria.

Table 7. Goodness of Fit . Test Results

\begin{tabular}{ccccc}
\hline Fcount & Ftable & Sig. & $\alpha$ \\
\hline 30,876 & $>$ & 2,4674 & 0,000 & $<$ \\
\hline
\end{tabular}

Source: Processed Primary Data, 2019

\section{Coefficient of Determination}

Table 8 shows that the Adjusted R Square value in this study is 0.547 , which means that $54.7 \%$ of variations in changes in formal credit access variables are influenced and can be explained by the guarantee value variable (X1), business turnover (X2), business age (X3), and the provision of accounting information (X4), while the remaining $45.3 \%$ is influenced by other not examined variables.

Table 8. Results of Adjusted R Square

\begin{tabular}{cccl}
\hline $\mathrm{R}$ & $R$ Square & Adjuste $R$ Square & Std. error of Estimate \\
\hline 0,752 & 0,565 & 0,547 & 14,83173 \\
\hline
\end{tabular}

Source: Processed Primary Data, 2019

t test

Hypothesis test in this study was carried out using a one-tailed t-test. Based on the error rate $(\alpha)=0.05$ and the degree of freedom: , $(\mathrm{n}-\mathrm{k})$, where $\mathrm{n}=100$ and $\mathrm{k}=5$, it is known that the $\mathrm{t}_{\text {table }}$ value for the one-tailed test is 1.6611 . Based on table 6 , it can be seen that the value of tcount for each variable is $\mathrm{t} 1=5.123, \mathrm{t} 2=2.866, \mathrm{t} 3=0.734$ and $\mathrm{t} 4=$ 4.337. The test results can be interpreted as follows:

a) First Hypothesis Test 
The results of hypothesis test in Table 6 show $t_{\text {count }}(5.123)>t_{\text {table }}(1.6611)$ with a value of Sig. $(0.000)<$ (0.05) which means that $\mathrm{H}_{\mathrm{a}}$ is accepted and $\mathrm{H}_{\mathrm{o}}$ is rejected. So it can be concluded that the first hypothesis (H1) is the value of the guarantee has a positive effect on access to formal credit in SMEs is accepted.

b) Second Hypothesis Test

The results of hypothesis test in Table 6 show $t_{\text {count }}(2.866)>t_{\text {table }}(1.6611)$ with a value of Sig. $(0.005)<$ (0.05) which means that $\mathrm{H}_{\mathrm{a}}$ is accepted and $\mathrm{H}_{\mathrm{o}}$ is rejected. So the second hypothesis (H2) which states that business turnover has a positive effect on access to formal credit in SMEs is accepted.

c) Third Hypothesis Test

The results of hypothesis test in Table 6 show tcount (0.734) ttable (1.6611) with Sig. (0.465) > (0.05) which means that Ha is rejected and Ho is accepted. So the third hypothesis (H3) which states that business age has a positive effect on access to formal credit in SMEs is rejected.

d) Fourth Hypothesis Test

The results of hypothesis test in Table 6 show tcount $(4,337)>$ ttable $(1,6611)$ with a value of Sig. $(0.000)<$ $(0.005)$ which means that $\mathrm{Ha}$ is accepted and Ho is rejected. Then the test results prove that the fourth hypothesis (H4), namely the provision of accounting information has a positive effect on access to formal credit in SMEs is accepted.

Discussion

The Effect of Collateral Value on Access to Formal Credit in SMEs

Based on the results of the first hypothesis test (H1), the results obtained which state that the value of the guarantee has a positive effect on access to formal credit in SMEs. This means that the greater the value of the guarantee provided in the loan application by SMEs, the greater the formal credit that can be accessed by SMEs.

Capital structure theory explained that there are two sources of capital, loan capital and own capital (Riyanto, 2011:296). The limited capital owned by SMEs encourages them to access credit from formal financial institutions. However, not all SMEs can access credit from financial institutions because based on Law Number 10 of 1998 article 8 (1), creditors need to have confidence that prospective debtors have ability and willingness to repay their loans. This confidence can be obtained through credit analysis based on 5C credit principles, collateral, capacity, capital, character and condition of economy.

The results of this study are in accordance with the credit principle (5C) that is collateral, where the guarantee provided by the debtor to the creditor is transfering of wealth that reflects the debtor's ability to bear the repayment of an obligation (credit), so that the guarantee serves as a protector for the creditor from the risk of loss if the debtor is unable to repay the credit. Therefore, the creditor needs to ensure that the value of the collateral submitted exceeds the amount of credit given. This conclusion is in line with research conducted by Kurniawan (2014) and Mersha and Ayenew (2017) which states that collateral has a positive and significant effect on credit access, meaning that the greater the guarantee in submitting a credit plan, the higher the probability of access to credit.

\section{Effect of Business Turnover on Access to Formal Credit for SMEs}

Test result from the second hypothesis (H2) prove that business turnover has a positive effect on access to formal credit in SMEs. This means that the greater the business turnover obtained by an SME, the greater the formal credit that can be accessed by SMEs.

The results of this study are in accordance with the credit principle (5C), that is capacity, where the creditor will assess the ability of prospective debtors to pay installments and pay off their loans on time which can be seen from the amount of turnover obtained. The results of this study are also in line with research conducted by Hardinata (2014) which states that business turnover is the highest priority after the value of collateral which affects the considerations of financial institutions in providing credit to SMEs.

\section{Effect of Business Age on Access to Formal Credit in SMEs}

Based on the results of the third hypothesis test (H3), the results obtained which state that business age has no significant effect on access to formal credit in SMEs. This means that the longer the business runs, it will not necessarily increase the amount of formal credit that can be accessed by SMEs. The results obtained by this study are in line with the results of Sujarwo's research (2016) which states that there is no significant positive relationship between length of business and access to credit.

In the principle of credit (5C) capacity, the debtor's ability to repay credit can also be assessed from the aspect of management or the ability to manage the business. The ability of the owner to manage the business can be seen from the age of the business, where the longer a person runs the business, the more his ability to manage the business will increase so that the greater the possibility of business success. The success of the business will also 
International Journal of Social Science (IJSS)

Vol.1 No.2 August 2021, pp: 55-68

ISSN: 2798-3463 (Printed) | 2798-4079 (Online)

DOI: https://doi.org/10.53625/ijss.v1i2.137

determine its ability to pay credit installments which in turn will increase access to credit. However, the results of this study found that there is no difference in the length of business of the majority of respondents who received a percentage of the amount of credit received compared to the amount of credit submitted at $100 \%$ and below $100 \%$. Most respondents who have a percentage of $100 \%$ are businesses that have been running for 5 years, while those with a percentage below $100 \%$ are also businesses that have been running for 5 years. So the results of this study are not in line with the principle of credit (5C) capacity.

The findings of this study also contradict wwith the findings of research conducted by Mersha and Ayenew (2017) which states that business age has a positive effect on access to formal credit. The results of interviews in the field with Bank BRI employees found that the age of the business did affect the decision to accept or not accept the credit application submitted by the prospective debtor, where credit below Rp. 25,000,000, the business has been running for at least 6 months, while credits above Rp. 100,000,000, the business has been running for at least 2 years. However, this does not significantly affect the percentage of the amount credit received compared to the amount credit applied. Because if the prospective debtor's business has good business prospects and the collateral submitted is greater than the amount of credit submitted, it is likely that the amount credit received will be the same as the amount of credit applied for $(100 \%)$, as long as the life of the business is in accordance with the specified credit requirements. .

Effect of Provision of Accounting Information on Access to Formal Credit in SMEs

Based on the results of the fourth hypothesis test $(\mathrm{H} 4)$, the results show that the provision of accounting information has a positive effect on access to formal credit. This means that the more accounting information a business provides, the greater the formal credit that SMEs can access.

In the principle of credit (5C) capital, credit analysts will measure the ability of prospective debtors to provide their own capital to support business financing. To assess the size of the capital owned, it is necessary to have accounting records so that the creditor can determine whether or not the prospective debtor is eligible to obtain credit. This statement is in accordance with the results of this study, that is the provision of accounting information has a positive effect on access to formal credit. The results of this study are also in line with the results of Mersha and Ayenew's research (2017) which states that accounting information has a positive effect on access to credit.

\section{CONCLUSION}

\section{Conclusion}

1. The guarantee value has a positive effect on access to formal credit for SMEs. This means, the greater the value of the guarantee, the greater the formal credit that can be accessed by SMEs.

2. Business turnover has a positive effect on access to formal credit for SMEs. This means, the greater the business turnover obtained, the greater the formal credit can be accessed by SMEs.

3. Age of business has no significant effect on access to formal credit for SMEs. This means, the longer the business has been running, it will not necessarily increase the amount of formal credit that can be accessed by SMEs.

4. Provision of accounting information has a positive effect on access to formal credit for SMEs. This means, the more accounting information provided, the greater the formal credit can be accessed by SMEs.

\section{Implication}

1. The results of this study found that the value of collateral, business turnover and the provision of accounting information can affect access to formal credit in SMEs. Therefore, in an effort to increase credit access to formal credit providing institutions, SMEs in Banyumas need to have assets that can be used as collateral where the value must be greater than the amount of credit submitted.

2. In addition, SME owners also need to improve their ability to manage their business to obtain optimal turnover so as to increase their ability to pay loan installments.

3. SMEs also need to make efforts to improve the provision of accurate accounting information so that it can make it easier for formal credit providers to assess actual business conditions.

4. The results of this study also found that business age had no effect on access to formal credit for SMEs. Thus, for SMEs that have a business age of less than 1 (one) year and need a loan (credit) there is no need to hesitate to apply for credit because the creditor does not mind the age of the business as long as the business age has met the specified credit requirements, which is more than 6 (six) months, the business has good business prospects and has a guarantee whose value is greater than the amount of credit applied for.

\section{Research Limitations}

This study still has limitations, that is when distributing the questionnaire there were several respondents who could not be found or were not willing to directly fill out the questionnaire, the researcher then took the questionnaire back the next day that had been determined. The absence of the researcher at the time of filling out the questionnaire resulted in not knowing whether the respondent had actually filled out the questionnaire properly. In addition, without 
being accompanied by the researcher directly, the respondent could not get an answer directly when there were difficulties encountered when answering the questionnaire.

\section{REFERENCES}

[1] Adawiyah, W. R. (2011). Faktor Penghambat Pertumbuhan Usaha Mikro Kecil Menengah (UMKM) (Studi di Kabupaten Banyumas). Sustainable Competitive Advantage (SCA), 1, (1), 1-18. Diakses dari http://jp.feb.unsoed.ac.id.

[2] Adirinekso, G. P. (2011). Akses UMKM ke Perbankan di Kabupaten Gunung Sleman. Jurnal Riset Manajemen dan Bisnis, 6, (1), 1-9. Diakses dari http://e-journalfb.ukdw.ac.id.

[3] Cooper, D. R., \& Schindler, P. S. (2014). Business Research Methods (Edisi 12). New York: McGrawHill/Irwin.

[4] Ghozali, I. (2009). Aplikasi Analisis Multivariate dengan Program SPSS. Semarang: Badan PenerbitUndip.

[5] Hardinata, Y. (2014). Analisis Keputusan Pemberian Kredit Modal Kerja Terhadap Usaha Kecil dan Menengah (Studi Kasus Pada Bank BRI KCP Sukun Malang). Jurnal Ilmiah Mahasiswa FEB, 2, (1), 1-17. Diakses dari http://jimfeb.ub.ac.id.

[6] Hartono, J. (2016). Metodologi Penelitian Bisnis : Salah Kaprah dan PengalamanPengalaman.Yogyakarta: BPFE.

[7] Juita, V. (2016). Pemanfaat SIA pada UMKM Sektor Jasa Perdagangan di Padang. Jurnal Riset Akuntansi Terpadu, 9, (1), 120-137. Diakses dari http://jurnal.untirta.ac.id/index.php/JRAT/article/view/4291/0.

[8] Kasmir. (2012). Manajemen Perbankan. Jakarta: Raja Grafindo Persada.

[9] Kurniawan. (2014). Faktor yang Mempengaruhi Akses Keuangan Pinjaman UMKM di Kabupaten Brebes. Prosiding, 4, (1), 1-15. Diakses dari http://jp.feb.unsoed.ac.id.

[10] Kusumaningtyas, I. (2016). Pengaruh Karakteristik Personal, Karakteristik Usaha, Karakteristik Kredit, dan Jaminan Terhadap Tingkat Pengembalian Kredit di BPR Nusamba Adiwerna Kabupaten Tegal Tahun 2016. BPPP Tegal, 1-20.

[11] Liliyah, Arie. (2015). Delapan Alasan Pelaku UMKM Enggan Mengambil Kredit Bank. Swa Online Magazine. Diakses dari https://swa.co.id/swa/trends/marketing/8-alasan- pelaku-umkm-enggan-mengambilkredit-bank.

[12] Maghfiroh, S., Amboningtyas, D., \& Gagah, E. (2018). Qualitative Analysis of Local Financial Statements and Financial Statements Based on Etap SAK (Case Study at UMKM in Banyumanik Semarang). Journal of Management, 4, (4), 1-8.

[13] Maisyaroh, A., \& Paramita, S. (2018). Pengaruh Persyaratan Kredit, Literasi Keuangan dan Demografi terhadap Akses Kredit Formal pada UMKM di Sidoarjo. Jurnal Ilmu Manajemen, 6, (3), 270-277. Diakses dari http://jurnalmahasiswa.unesa.ac.id.

[14] Marta, J., \& Satria, D. (2015). Dampak Jaminan terhadap Peluang Memperoleh Kredit bagi UMKM di Sumatera Barat. Jurnal Ekonomi dan Pembangunan Indonesia, 16, (1), 1-14. Doi: http://dx.doi.org/10.21002/jepi.v16i1.457.

[15] Mersha, D., \& Ayenew, Z. (2017). Determinants of Access to Formal Financial Sources of Micro and Small Enterprises (MSEs) in West Oromia Region, Ethiopia . International Journal of Business and Economics Research, 6, (5), 100-110. Doi: 10.11648/j.ijber.20170605.13.

[16] Muljono, T. P. (2001). Manajemen Perkreditan bagi Bank Komersil. Yogyakarta: BPFE. Nkundabanyanga, S. K., Kasozi, D., Nalukenge, I., \& Tauringana, V. (2014). Lending Terms,Financial Literacy and Formal Credit Accessibility. International Journal of Social Economics, 41, (5), 1-19. Doi: 10.1108/IJSE-03-2013-0075.

[17] Oktavianti, V., Hakim, M.S., Kunaifi, A. (2017). Pengaruh Literasi Keuangan dan Persyaratan Kredit terhadap Akses Kredit Formal pada UMKM di Surabaya. Jurnal Sains dan Seni ITS, 6, (1), 12-16. Doi: 10.12962/j23373520.v6i1.21320.

[18] Republik Indonesia. Undang-Undang Nomor 10 tahun 1998 tentang Perubahan atas Undang-Undang Nomor 7 Tahun 1992 tentang Perbankan.

[19] Riyanto, B. (2011). Dasar-dasar Pembelanjaan Perusahaan (Edisi 4). Yogyakarta: BPFE. Rudiantoro, R., \& Verinica, S. (2012). Kualitas Laporan Keuangan UMKM serta Prospek Implementasi SAK ETAP. Jurnal Akuntansi dan Keuangan Indonesia, 9, (1), 1-21. Doi: 10.21002/jaki.2012.01.

[20] Samora, Remon. (2018). Kredit UMKM Lambat, Apa Masalahnya? Tulisan pada https://nasional.sindonews.com/read/1277492/18/kredit umkm-lambat-apa- masalahnya1517180327. 
International Journal of Social Science (IJSS)

Vol.1 No.2 August 2021, pp: 55-68

ISSN: 2798-3463 (Printed) | 2798-4079 (Online)

DOI: $\underline{\text { https://doi.org/10.53625/ijss.v1i2.137 }}$

[21] Sholikha, D.L. (2015). Pengaruh Penilaian Kelayakan Kredit dan Informasi Akuntansi terhadap Keputusan Pemberian Kredit pada Bank UMUM di Surabaya. Sekolah Tinggi Ilmu Ekonomi Perbanas.Surabaya. Diakses darihttp://eprints.perbanas.ac.id/290/1/ARTIKEL\%20ILMIAH.pdf.

[22] Suhardjono. (2003). Manajemen Perkreditan UMKM. Yogyakarta : UPP AMP YKPN.

[23] Sujarwo. (2016). Akses UMKM Pada Kredit Bank. Jurnal PNJ, 1-9. Diakses dari https://jurnal.pnj.ac.id. 
